\title{
Epistatic interaction between variations in the angiotensin | converting enzyme and angiotensin || type 1 receptor genes in relation to extent of coronary atherosclerosis
}

\author{
S Ye, S Dhillon, R Seear, L Dunleavey, L B Day, W Bannister, I N M Day, I Simpson
}

Heart 2003;89:1 195-1199

See end of article for authors' affiliations

.....................

Correspondence to: Dr S Ye, Human Genetics Division, University of Southampton School of Medicine, Duthie Building (mailpoint 808),

Southampton General

Hospital, Southampton

SO16 6YD, UK;

Shu.Ye@soton.ac.uk

Accepted 10 March 2003

\begin{abstract}
Objective: To test the hypothesis that gene-gene interaction of the renin-angiotensin system is associated with an effect on the extent of coronary atherosclerosis.

Setting and results: A cohort of 1162 patients with coronary artery disease were genotyped for genetic polymorphisms in the renin-angiotensin system. Patients carrying the $D$ allele of the angiotensin I converting enzyme (ACE) gene had greater coronary extent scores (defined as the number of coronary segments with $5 \%$ to $75 \%$ stenosis) than those not carrying this allele $(p=0.006$ in non-parametric analysis and $p=0.019$ in parametric analysis). This association remained significant after adjusting for age, body mass index, hypertension, and diabetes, which were also significantly associated with coronary extent scores. There was a significant interaction ( $p=0.033)$ between genotypes of ACE and angiotensin II type 1 receptor (AGTR 1). The association between the ACE gene D allele and increased coronary extent scores was significant $(p=0.008$ in non-parametric and $p=0.027$ in parametric analysis) in those carrying the $+1166 \mathrm{C}$ allele of the AGTR 1 gene, but was absent in those not carrying the AGTR 1 gene $+1166 \mathrm{C}$ allele.

Conclusion: These findings suggest that variation in the ACE and AGTR 1 genes and their interaction may not only contribute to susceptibility of coronary artery disease as previously found but also modify the disease process, thus contributing to interindividual differences in severity of the disease.
\end{abstract}

The renin-angiotensin system includes a two enzyme cascade where angiotensinogen (AGT) is cleaved by renin to form angiotensin $\mathrm{I}$, which in turn is processed by angiotensin I converting enzyme (ACE) to generate the effector peptide angiotensin II. The effects of angiotensin II are mediated by cell surface receptors, angiotensin II type 1 receptor (AGTRl), and angiotensin II type 2 receptor (AGTR2). In addition to its role in regulating vascular tone and arterial blood pressure, this system is also involved in vascular endothelial dysfunction and apoptosis, lipoprotein peroxidation, proinflammatory cytokine production, vascular smooth muscle cell proliferation, and vascular matrix synthesis, all of which are important mechanisms in the formation and progression of atherosclerosis. ${ }^{1-3}$

In view of the pathophysiological role of the reninangiotensin system and the established benefits of ACE inhibitor, ${ }^{4}$ it has been proposed that genetic variants affecting the function of this system are candidates for genetic factors for cardiovascular disease. A polymorphism resulting from the insertion (I)/deletion (D) of 287 nucleotides in intron 16 of the ACE gene has been extensively studied in relation to risk of myocardial infarction..$^{5-8}$ It has also been shown that the ACE I/D polymorphism and a polymorphism arising from an $\mathrm{A}>\mathrm{C}$ substitution at nucleotide position 1166 in the AGTRl gene exert synergistic effects on risk of myocardial infarction, such that the ACE D/D genotype is associated with increased risk of myocardial infarction only in those carrying the AGTRl $+1166 \mathrm{C}$ allele.'

The severity of coronary atherosclerosis positively correlates with levels of AGTRl expression in coronary arteries. ${ }^{10}$ In this study, we tested the hypothesis that the above mentioned epistatic interaction between the ACE and AGTRl genes is also associated with an effect on the extent of coronary atheroscle- rosis. The ACE gene I/D polymorphism and the AGTRl gene $+1166 \mathrm{~A}>\mathrm{C}$ polymorphism were analysed in a cohort of 1162 white British patients with angiographically documented coronary artery disease (CAD). In addition, we examined whether the extent of coronary atherosclerosis was associated with variation in the AGT and AGTR2 genes, which are also components of the renin-angiotensin system.

\section{SUBJECTS AND METHODS \\ Subjects}

We studied a cohort of 1162 patients with angiographically documented CAD. All were white and were recruited from consecutive patients undertaking diagnostic and interventional coronary arteriography in the Wessex Cardiothoracic Unit, Southampton General Hospital, from May 1999 to March 2002. The study was approved by the south and west local research ethics committee, and all subjects gave written consent.

We recorded demographic and clinical data including age, sex, weight, height, occupation, smoking habit, and number of cigarettes consumed per day by each smoker, the presence or absence of hyperlipidaemia (defined as cholesterol concentration $>5.2 \mathrm{mmol} / \mathrm{l}$ or triglyceride concentration $>3 \mathrm{mmol} / \mathrm{l}$ ), current medications, particularly the use of lipid lowering drugs, the presence or absence of hypertension (defined as

Abbreviations: $A C E$, angiotensin I converting enzyme; $A G T$, angiotensinogen; AGTR 1, angiotensin II type 1 receptor; AGTR2, angiotensin II type 2 receptor; CAD, coronary artery disease; D, deletion; $\mathrm{I}$, insertion; PCR, polymerase chain reaction 
Table 1 Characteristics of patients

Mean (SD) (for continuous variables) or counts (for categorical variables)

Age (years)

Sex (male/female)

$63.27(9.95)$

Body mass index $\left(\mathrm{kg} / \mathrm{m}^{2}\right.$

$886 / 276$

$27.50(4.25)$

Smoking history (current/former/never

smoker)

Hypercholesterolaemia (yes/no)

$120 / 742 / 300$

Hypertension (yes/no)

Type I diabetes (yes/no)

$953 / 209$

$521 / 641$

$37 / 1125$

$118 / 1044$

Type II diabetes (yes/no)

$565 / 597$ diastolic blood pressure $>95 \mathrm{~mm} \mathrm{Hg}$ or systolic blood pressure $>160 \mathrm{~mm} \mathrm{Hg}$ ), the presence or absence of type I or type II diabetes, the presence or absence of previous myocardial infarction, and the presence or absence of CAD in first degree relatives under 65 years of age. Total cholesterol and triglyceride concentrations were measured by the clinical chemistry department of the Southampton General Hospital using standard quality controlled enzymatic methods. Table 1 summarises the characteristics of the patients.

Coronary angiograms were analysed by a consultant cardiologist. The extent of CAD was assessed using a scoring system described by Moise and colleagues ${ }^{11}{ }^{12}$ and the coronary extent score was defined as the number of coronary segments ( 15 in total) with 5\% to $75 \%$ stenosis. This extent score definition is related to a pathophysiological rather than a haemodynamic concept: the minimal and moderate lesions have a high potential for progression, whereas the more severe (>80\%) lesions are more likely subject to thrombotic, occlusive modifications than to a primary atherogenic progression. ${ }^{11}{ }^{12}$ This scoring system has been used in a number of other studies. ${ }^{12}{ }^{13}$ The reproducibility of this method has been previously assessed, with an overall variability of $14.1 \% .^{12}{ }^{14}$

Given that the ACE gene D allele and the AGTRl gene C allele had population frequencies of approximately 0.5 and 0.3 , respectively, and on the basis of findings in previous studies that the ACE gene I/D polymorphism was associated with an odds ratio of about 1.2 whereas the AGTRl gene A+1166C polymorphism per se was not associated with $\mathrm{CAD}^{5-8}$ this study had $80 \%$ power to detect a gene-gene interaction associated with a $10 \%$ increase in CAD risk in a two sided analysis at the 0.05 significance level. ${ }^{15} 16$

\section{Genotype analyses}

A $10 \mathrm{ml}$ blood sample was taken from each subject and DNA was extracted using a salt precipitation method. ${ }^{17}$ Genotypes for the ACE I/D polymorphism were determined with the use of an allele specific polymerase chain reaction (PCR) method described by Evans and colleagues. ${ }^{18}$ Genotypes for the AGT gene T174M, AGTRl gene $+1166 \mathrm{~A}>\mathrm{C}$, and the AGTR2 gene $+1291 \mathrm{G}>\mathrm{T}$ and $+1297 \mathrm{G}>\mathrm{A}$ polymorphisms were determined with the use of the tetraprimer amplification refractory mutation system PCR method as described previously. ${ }^{19}$ Table 2 gives the primer sequences and PCR conditions. Each PCR reaction was performed in a total volume of $10 \mu \mathrm{l}$ containing $20 \mathrm{ng}$ of template DNA, $1 \times$ PCR buffer (Life Technologies, Paisley, UK), $200 \mu \mathrm{M}$ deoxynucleotide triphosphate, appropriate concentrations of primers and $\mathrm{MgCl}_{2}$ as described in table 2, $1.5 \mathrm{M}$ Betaine and $0.5 \mathrm{U}$ DNA Taq polymerase. A $5 \mu \mathrm{l}$ aliquot of PCR product was subjected to microplate array diagonal gel electrophoresis. ${ }^{20}$ The gel was stained with Vistra green (Amersham Pharmacia Biotech, Little Chalfont, UK) and scanned with a fluorimager 595 (Molecular Dynamics, Sunnyvale, California, USA)

\section{Statistical analyses}

$\chi^{2}$ analyses were performed to test whether the observed genotype distributions deviated from Hardy-Weinberg equilibrium. The Kruskal-Wallis non-parametric test and analysis of variance were used to examine whether coronary extent scores differed between patients with different genotypes. To test whether the reported epistatic interaction between the ACE gene D allele and the AGTRl gene $+1166 \mathrm{C}$ allele was also associated with an effect on the extent of coronary atherosclerosis, we used the same genetic model as previously described ${ }^{9}$ - that is, the relation between coronary extent score and ACE genotype was assessed separately in groups of subjects with different AGTIR genotypes. The analyses were carried out using the SPSS package (version 11 , SPSS Inc, Chicago, Illinois, USA).

\section{RESULTS}

A cohort of 1162 patients with angiographically documented CAD were genotyped for the ACE gene I/D, AGT gene T174M,

Table 2 Polymerase chain reaction primers and conditions

\begin{tabular}{|c|c|c|c|}
\hline Polymorphism & Primer sequence and concentration & $\begin{array}{l}\text { Annealing } \\
\text { temperature } \\
\left({ }^{\circ} \mathrm{C}\right)\end{array}$ & $\begin{array}{l}\mathrm{MgCl}_{2} \\
(\mathrm{mM})\end{array}$ \\
\hline ACE I/D & $\begin{array}{l}\text { ACE1 (D allele specific): 5'-CATCCTTTCTCCCATTTCTC, } 800 \mathrm{nM} \\
\text { ACE2 (I allele specific): 5'-TGGGATTACAGGCGTGATACAG, } 800 \mathrm{nM} \\
\text { ACE3: 5'-ATTTCAGAGCTGGAATAAAATT, } 240 \mathrm{nM}\end{array}$ & 50 & 1.5 \\
\hline AGT T174M & $\begin{array}{l}\text { Forward inner primer (T allele specific): 5'-CTGGGGCTGTGAACACGCCCACCAACA, } 100 \mathrm{nM} \\
\text { Reverse inner primer (C allele specific): 5'-TGATAGCCAGGCCCAGCTGCTGCTGTCAAC, } 100 \mathrm{nM} \\
\text { Forward outer primer : 5'-TCTCCCCAACGGCTGTCTTTGGCACCCT, } 10 \mathrm{nM} \\
\text { Reverse outer primer: 5'-CACTGGCTCCCATCAGGGAGCAGCCAGT, } 10 \mathrm{nM}\end{array}$ & 55 & 2 \\
\hline AGTR $1+1166$ A $>C$ & $\begin{array}{l}\text { Forward inner primer (A allele specific): 5'-TCTGCAGCACTTCACTACCAAATGAACA, } 1000 \mathrm{nM} \\
\text { Reverse inner primer (C allele specific): 5'-TCTCCTTCAATTCTGAAAAGTAGCTGAG, } 1000 \mathrm{nM} \\
\text { Forward outer primer: 5'-GCCAAATCCCACTCAAACCTTTCAACAA, } 100 \mathrm{nM} \\
\text { Reverse outer primer: 5'-AAGCAGGCTAGGGAGATTGCATTTCTGT, } 100 \mathrm{nM}\end{array}$ & 58 & 3.5 \\
\hline AGTR2 + 1291G>T & $\begin{array}{l}\text { Forward inner primer (T allele specific): 5'-TTGTTTTTCTGATATGTTTGTACAAGACTT, } 600 \mathrm{nM} \\
\text { Reverse inner primer (G allele specific): 5'-TCTAGGTTGTAAATATGTCTCACYAATAAC, } 600 \mathrm{nM} \\
\text { Outer forward primer: 5'-AATAAAATTCCCCTAATCTTTCTGAA, } 200 \mathrm{nM} \\
\text { Outer reverse primer: 5'-GGAAATCCTGATAAAAATGGATATAAAA, } 200 \mathrm{nM}\end{array}$ & 54 & 3.5 \\
\hline AGTR2 + 1297G>A & $\begin{array}{l}\text { Forward inner primer (G allele specific): 5'-TCTGATATGTTTGTACAAGATTKTCAGTG, } 600 \mathrm{nM} \\
\text { Reverse inner primer (A allele specific): 5'-GTTACTTCTAGGTTGTAAATATGTCTCCCT, } 600 \mathrm{nM} \\
\text { Outer forward primer: 5'-AATAAAATTCCCCTAATCTTTCTGAA, } 200 \mathrm{nM} \\
\text { Outer reserve primer: 5'-GGAAATCCTGATAAAAATGGATATAAAA, } 200 \mathrm{nM}\end{array}$ & 56 & 3.5 \\
\hline
\end{tabular}


Table 3 Effect of genotypes on coronary extent scores

\begin{tabular}{|c|c|c|c|c|c|c|c|c|}
\hline \multirow[b]{2}{*}{ Polymorphism } & \multirow[b]{2}{*}{ Genotype } & \multirow[b]{2}{*}{$N$} & \multicolumn{2}{|c|}{ Non-parametric test } & \multicolumn{2}{|c|}{ Analysis of variance } & \multicolumn{2}{|c|}{ Multivariate analysis of variance } \\
\hline & & & Mean rank & $\mathrm{p}$ Value & Mean score & $\mathrm{p}$ Value & Mean score* & $\mathrm{p}$ Value* \\
\hline \multirow[t]{3}{*}{ ACE I/D } & $D / D$ & 343 & 592.59 & $0.024 \dagger$ & 0.98 & $0.061 \dagger$ & 0.98 & $0.072 \dagger$ \\
\hline & I/D & 587 & 595.06 & $0.006 \ddagger$ & 1.00 & $0.019 \ddagger$ & 0.99 & $0.024 \ddagger$ \\
\hline & $1 / 1$ & 232 & 530.79 & & 0.81 & & 0.82 & \\
\hline \multirow{3}{*}{ AGT T174M } & $\mathrm{T} / \mathrm{T}$ & 863 & 579.44 & NS & 0.98 & NS & 0.97 & NS \\
\hline & $\mathrm{T} / \mathrm{M}$ & 264 & 584.46 & & 0.98 & & 0.98 & \\
\hline & $M / M$ & 29 & 496.12 & & 0.69 & & 0.69 & \\
\hline \multirow[t]{3}{*}{ AGTR1 A+1166C } & $A / A$ & 559 & 563.04 & NS & 0.96 & NS & 0.96 & NS \\
\hline & $\mathrm{A} / \mathrm{C}$ & 458 & 570.67 & & 0.97 & & 0.96 & \\
\hline & $\mathrm{C} / \mathrm{C}$ & 113 & 556.69 & & 0.93 & & 0.93 & \\
\hline \multirow[t]{5}{*}{ AGTR2 + 1291G>T } & $G$ (male) & 665 & 445.65 & NS & 0.97 & NS & 0.93 & NS \\
\hline & $T$ (male) & 220 & 435.00 & & 0.90 & & 0.90 & \\
\hline & G/G (female) & 151 & 141.40 & NS & 1.07 & NS & 1.07 & NS \\
\hline & $\mathrm{G} / \mathrm{T}$ (female) & 112 & 139.29 & & 1.00 & & 1.01 & \\
\hline & $\mathrm{T} / \mathrm{T}$ (female) & 14 & 110.79 & & 0.64 & & 0.73 & \\
\hline \multirow{5}{*}{ AGTR2 + 1297G>A } & $G$ (male) & 453 & 435.07 & NS & 0.91 & NS & 0.90 & NS \\
\hline & A (male) & 433 & 452.32 & & 1.00 & & 1.00 & \\
\hline & G/G (female) & 66 & 138.65 & NS & 1.03 & NS & 1.08 & NS \\
\hline & $\mathrm{G} / \mathrm{A}$ (female) & 137 & 139.27 & & 1.05 & & 1.04 & \\
\hline & $\mathrm{A} / \mathrm{A}$ (female) & 71 & 133.01 & & 0.97 & & 0.99 & \\
\hline
\end{tabular}

AGTR1 gene $+1166 \mathrm{~A}>\mathrm{C}$, and AGTR2 gene $+1291 \mathrm{G}>\mathrm{T}$ and $+1297 \mathrm{G}>$ A polymorphisms. Table 1 summarises the characteristics of the patients. The genotype frequencies for all polymorphisms were consistent with Hardy-Weinberg equilibrium. The frequencies of the ACE gene D, AGT gene 174M, AGTR1 gene +1166C, AGTR2 gene + 1291T, and AGTR2 gene $+1297 \mathrm{~A}$ alleles were 0.55, 0.14, 0.30, 0.25, and 0.50, respectively, similar to findings from other studies of white subjects. ${ }^{21}$ There was no difference between genotype groups in age, sex, body mass index, plasma cholesterol concentration, plasma triglyceride concentration, hypertension, diabetes, and incidence of myocardial infarction.

A significant association was observed between the ACE gene I/D polymorphism and the extent of coronary atherosclerosis, such that patients carrying the D allele had higher coronary extent scores than those not carrying this allele $(\mathrm{p}=0.006$ in non-parametric analysis and $\mathrm{p}=0.019$ in parametric analysis; table 3 ). The association between the $\mathrm{D}$ allele bearing genotypes and greater coronary extent scores remained significant $(\mathrm{p}=0.024)$ after adjusting for other risk factors that were also significantly associated with coronary extent scores, including age, body mass index, hypertension, and diabetes (table 3). No association was detected between coronary extent scores and the other polymorphisms studied, when they were analysed individually.

Since an epistatic interaction between the ACE gene I/D and AGTRl gene $+1166 \mathrm{~A}>\mathrm{C}$ polymorphisms in determining risk of myocardial infarction had been reported, we examined whether this epistatic interaction was also associated with the extent of coronary atherosclerosis, using the same genetic model as previously described. ${ }^{9}$ Analysis of variance with coronary extent score as the dependent variable showed a significant interaction $(p=0.033)$ between ACE and AGTRl genotypes. Further analyses showed that the association between the ACE gene I/D polymorphism and coronary extent scores was highly significant $(\mathrm{p}=0.008$ in non-parametric analysis and 0.027 in parametric analysis with adjustment for covariates) in patients carrying the $\mathrm{C}$ allele of the AGTRl gene $+1166 \mathrm{~A}>\mathrm{C}$ polymorphism, but was absent in those not carrying the AGTRl gene $\mathrm{C}$ allele (fig 1). There was no interaction between the other polymorphisms studied.

\section{DISCUSSION}

Following the landmark study of Cambien and colleagues, ${ }^{22}$ which showed an association between the ACE gene I/D polymorphism and risk of myocardial infarction, there has been a large number of studies on this and other genetic variants in the renin-angiotensin system in relation to various cardiovascular disorders. There is now compelling evidence of a strong association between the D allele of the ACE gene and increased plasma ACE concentrations. ${ }^{23}$ Many studies have also shown that the ACE gene D allele is associated with a modest increase in risk of CAD, myocardial infarction, and ischaemic cerebrovascular disease..$^{5-8}$ In this study, we tested the hypothesis that genetic variation in this system was also associated with an effect on the extent of coronary atherosclerosis in patients with CAD. A large cohort of patients with angiographically documented CAD was genotyped for polymorphisms in the ACE, AGT, AGTR1, and AGTR2 genes. Extent of coronary atherosclerosis was found to be greater in patients carrying the ACE gene D allele than in those not carrying this allele. In addition, we detected an epistatic interaction between the ACE gene I/D and AGTRI + $1166 \mathrm{~A}>\mathrm{C}$ polymorphisms, with a synergistic effect of the ACE gene D and AGTR I gene $+1166 \mathrm{C}$ alleles on the extent of coronary atherosclerosis.

The data from this study indicate that variation in the ACE and AGTRl genes may act as genetic modifiers of atherosclerosis. Atherosclerosis is a multifactorial, polygenic disease whose pathogenesis involves gene-gene and geneenvironment interactions. The genetic factors may be classified as susceptibility genes and modifier genes; the former contribute to the initiation of the pathogenesis and the latter influence the progression and severity of the disease after it has been initiated. ${ }^{24-26}$ Identifying the susceptibility genes and modifier genes, as well as their interactions, will help our understanding of the disease mechanisms and may identify targets for developing novel treatment measures.

The I/D polymorphism of the ACE gene arises from the presence or absence of a 287 base pair Alu repeat element in intron 16, and it remains unclear whether this polymorphism itself has a functional effect on the expression or function of ACE or marks the effect of certain functional polymorphism(s) nearby through linkage disequilibrium. Addressing this question would be a challenging task, especially as the I/D polymorphism is in absolute linkage disequilibrium with at 



Figure 1 Bar charts showing an association of angiotensin I converting enzyme (ACE) genotype with coronary extent score only in patients carrying the angiotensin II type 1 receptor gene $+1166 \mathrm{C}$ allele. (A) Mean rank in non-parametric test; (B) mean score after adjusting for age, body mass index, hypertension, and diabetes in multivariate analysis of variance. Light grey bars: ACE deletion D/D genotype; open bars: ACE insertion I/D genotype; dark grey bars: ACE I/I genotype.

least 17 other polymorphic sites at the ACE locus. ${ }^{27}$ Similarly, it is unknown whether the AGTRl gene +1166 A>C polymorphism, which is located in the $3^{\prime}$ untranslated region of the gene, has a direct functional effect.

A previous study in white Germans showed that the AGT Tl74M polymorphism was associated with the extent of coronary atherosclerosis. ${ }^{28}$ The present study in white British subjects did not detect such an association. The discrepant findings between the two studies may be due to different genetic backgrounds between the two samples or other factors. There has been no reported study on AGTR2 gene variation in relation to coronary atherosclerosis. Although the AGTR2 gene is also a good candidate, particularly as it is located in a region on the $\mathrm{X}$ chromosome that has been shown to be in linkage with $\mathrm{CAD}^{29}$ we did not detect an association between the AGTR2 gene polymorphisms studied and the extent of coronary atherosclerosis.

In summary, this study has identified a synergistic effect of the ACE and AGTRl genes on the extent of coronary atherosclerosis. The finding suggests that variation in the ACE and AGTRl genes and their interaction may not only contribute to susceptibility of CAD as previously found" but also modify the disease process, thus contributing to interindividual differences in severity of the disease.

\section{ACKNOWLEDGEMENTS}

This work was supported by the British Heart Foundation (grants PG/98183). SD was funded by the UK Medical Research Council (G9828424).

\section{Authors' affiliations}

S Ye, S Dhillon, R Seear, L Dunleavey, L B Day, I N M Day, Human Genetics Division, University of Southampton School of Medicine,

Southampton, UK

W Bannister, I Simpson, Wessex Cardiothoracic Unit, Southampton University NHS Trusts, Southampton, UK

\section{REFERENCES}

1 Schmidt-Ott KM, Kagiyama S, Phillips MI. The multiple actions of angiotensin II in atherosclerosis. Regul Pept 2000;93:65-77.

2 Libby P. Current concepts of the pathogenesis of the acute coronary syndromes. Circulation 2001;104:365-72.

3 Weiss D, Sorescu D, Taylor WR. Angiotensin II and atherosclerosis. Am J Cardiol 2001;87:25C-32C.

4 Anon. Indications for ACE inhibitors in the early treatment of acute myocardial infarction: systematic overview of individual data from 100,000 patients in randomized trials. ACE Inhibitor myocardial infarction collaborative group. Circulation 1998;97:2202-12.

5 Samani NJ, Thompson JR, O'Toole L, et al. A meta-analysis of the association of the deletion allele of the angiotensin-converting enzyme gene with myocardial infarction. Circulation 1996;94:708-12.

6 Staessen JA, Wang JG, Ginocchio G, et al. The deletion/insertion polymorphism of the angiotensin converting enzyme gene and cardiovascular-renal risk. J Hypertens 1997; 15:1579-92.

7 Agerholm-Larsen B, Nordestgaard BG, Tybjaerg-Hansen A. ACE gene polymorphism in cardiovascular disease: meta-analyses of small and large studies in whites. Arterioscler Thromb Vasc Biol 2000;20:484-92.

8 Keavney B, McKenzie C, Parish S, et al. Large-scale test of hypothesised associations between the angiotensin- converting-enzyme insertion/deletion polymorphism and myocardial infarction in about 5000 cases and 6000 controls. International studies of infarct survival (ISIS) collaborators. Lancet 2000:355:434-42.

9 Tiret L, Bonnardeaux A, Poirier O, et al. Synergistic effects of angiotensin-converting enzyme and angiotensin-ll type 1 receptor gene polymorphisms on risk of myocardial infarction. Lancet 1994;344:910-3.

10 Gross CM, Gerbaulet S, Quensel C, et al. Angiotensin II type 1 receptor expression in human coronary arteries with variable degrees of atherosclerosis. Basic Res Cardiol 2002;97:327-33.

11 Moise A, Theroux P, Taeymans Y, et al. Clinical and angiographic factors associated with progression of coronary artery disease. J Am Coll Cardiol 1984:3:659-67.

12 Moise A, Clement B, Saltiel J. Clinical and angiographic correlates and prognostic significance of the coronary extent score. Am J Cardiol 1988;61:1255-9.

13 Moise A, Lesperance J, Theroux $\mathrm{P}$, et al. Clinical and angiographic predictors of new total coronary occlusion in coronary artery disease: analysis of 313 nonoperated patients. Am J Cardiol 1984;54:1176-81.

14 Sanmarco ME, Brooks SH, Blankenhorn DH. Reproducibility of a consensus panel in the interpretation of coronary angiograms. Am Heart J 1978;96:430-7.

15 Gauderman WJ. Sample size requirements for association studies of gene-gene interaction. Am J Epidemiol 2002;155:478-84.

16 Lutucuta S, Ballantyne CM, Elghannam H, et al. Novel polymorphisms in promoter region of ATP binding cassette transporter gene and plasma lipids, severity, progression, and regression of coronary atherosclerosis and response to therapy. Circ Res 2001;88:969-73.

17 Miller SA, Dykes DD, Polesky HF. A simple salting out procedure for extracting DNA from human nucleated cells. Nucleic Acids Res 1988;16:1215

18 Evans $\mathbf{A E}$, Poirier $\mathrm{O}$, Kee $\mathrm{F}$, et al. Polymorphisms of the angiotensin-converting-enzyme gene in subjects who die from coronary heart disease. QJM 1994;87:211-4.

19 Ye S, Dhillon S, Ke X, et al. An efficient procedure for genotyping single nucleotide polymorphisms. Nucleic Acids Res 2001;29:E88.

20 Day IN, Humphries SE. Electrophoresis for genotyping: microtiter array diagonal gel electrophoresis on horizontal polyacrylamide gels, hydrolink, or agarose. Anal Biochem 1994;222:389-95.

21 Wang JG, Staessen JA. Genetic polymorphisms in the renin-angiotensin system: relevance for susceptibility to cardiovascular disease. Eur J Pharmacol 2000;410:289-302.

22 Cambien F, Poirier O, Lecerf L, et al. Deletion polymorphism in the gene for angiotensin-converting enzyme is a potent risk factor for myocardial infarction. Nature 1992;359:641-4.

23 Tiret L, Rigat B, Visvikis S, et al. Evidence, from combined segregation and linkage analysis, that a variant of the angiotensin I-converting enzyme (ACE) gene controls plasma ACE levels. Am J Hum Genet 1992;51:197-205. 
24 Attie AD. Atherosclerosis modified. Circ Res 2001:89:102-4. 25 Nadeau JH. Modifier genes in mice and humans. Nat Rev Genet $2001 ; 2: 165-74$

26 Dipple KM, McCabe ER. Phenotypes of patients with "simple" Mendelian disorders are complex traits: thresholds, modifiers, and systems dynamics. Am J Hum Genet 2000;66:1729-35.

27 Rieder MJ, Taylor SL, Clark AG, et al. Sequence variation in the human angiotensin converting enzyme. Nat Genet 1999;22:59-62.
28 Gardemann A Stricker J, Humme J, et al. Angiotensinogen T174M and M235T gene polymorphisms are associated with the extent of coronary atherosclerosis. Atherosclerosis 1999;145:309-14.

29 Pajukanta P, Cargill M, Viitanen L, et al. Two loci on chromosomes 2 and $X$ for premature coronary heart disease identified in early- and late-settlement populations of Finland. Am J Hum Genet 2000;67:1481-93

\section{IMAGES IN CARDIOLOGY}

\section{Brugada-like acute myocardial infarction}

A

59 year old woman presented with chest pain radiating to the left arm and accompanied by dyspnoea and sweating. Her symptoms began at 2:30 am. Upon arrival, the ECG showed saddleback ST segment elevations in leads Vl-V3. The diagnosis of acute myocardial infarction was made and the patient was transferred to the regional centre for primary angioplasty. Coronary angiography revealed an occlusion in the proximal segment of the left anterior descending artery (upper panels). The pain to balloon time was five hours. Cardiac markers were raised (creatine kinase (CK) 1547 U/l, CK-MB 375 U/l). ST segment elevations changed from saddleback to coved (lower panels) with slow resolution during the first week. Neither the patient nor her family had had any signs or symptoms of Brugada syndrome.

This case illustrates that not only can Brugada syndrome be mistaken for acute myocardial infarction but that the reverse may also occur.







Coronarography before (left panel) and after (right panel) percutaneous coronary intervention. Arrow indicates left anterior descending coronary artery occlusion.


ECGs of the same patient with myocardial infarction, recorded only hours apart. The ST segment elevation changed from saddleback (left) to coved (middle and right) in leads V1-V3. 